\title{
545
}

589

opy 1

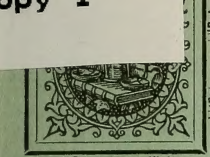

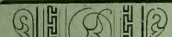
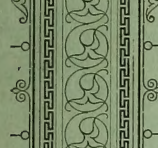

\section{SILK GROWING.}

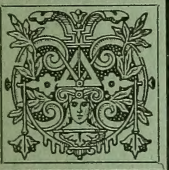

(कापा खाया
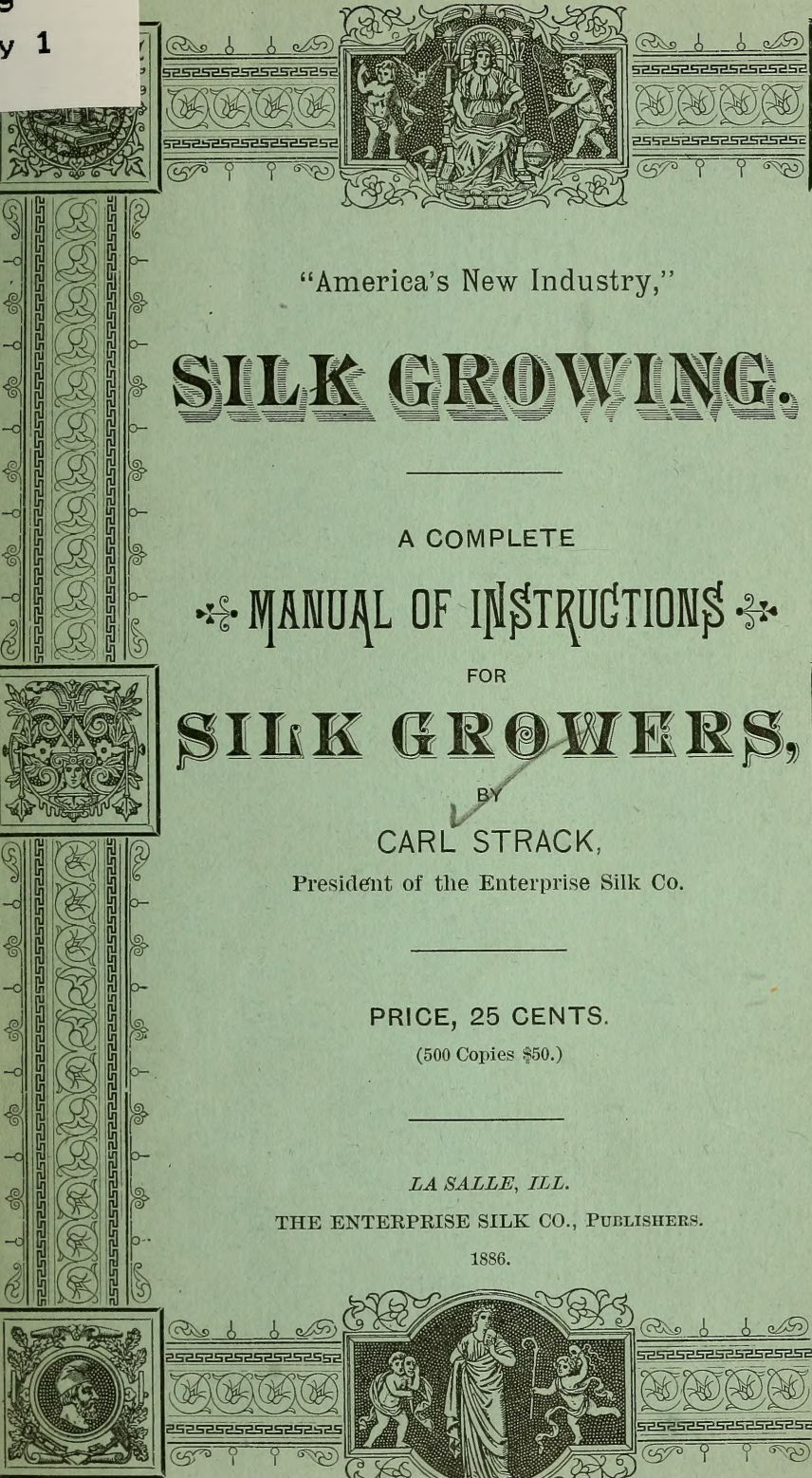

"America's New Industry,"

A COMPLETE

$\because$ MANUALL OF INSTRUCTIONS $\%$

FOR

SILK GROIKRS,

CARL STRACK,

President of the Enterprise Silk Co.

PRICE, 25 CENTS.

(500 Copies $\$ 50$.)

LA SALLE, ILL.

THE ENTERPRISE SILK CO., Publishers.

1886.

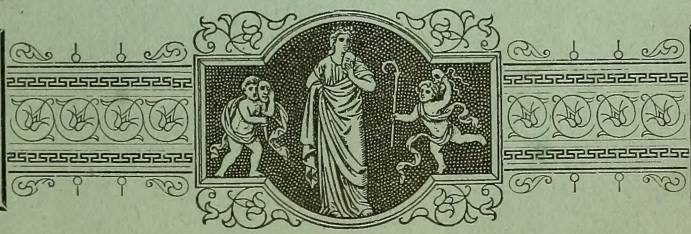

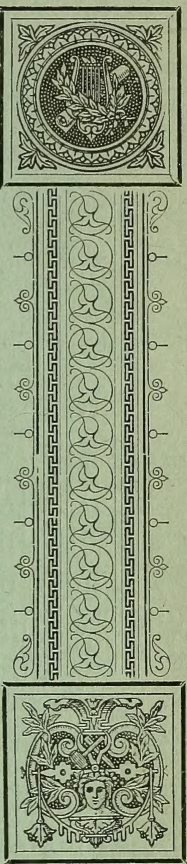
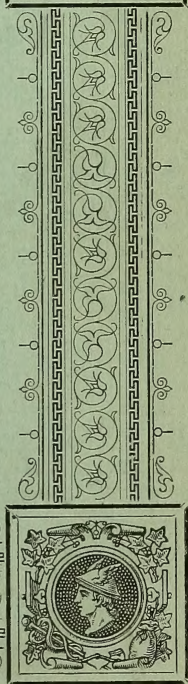


\section{CONTENTS.}

Page.

Preface ............................................... 3

The Silk Worm-The Egg …..................... 5

Wintering the Eggs ................................ 5

Hatching the Eggs................................ 8

The Worm ............................................ 9

Feeding and Rearing the Worm,

First Age......................................... 10

Second, Third and Fourth Ages.....................12

Preparations for Spinning .................................. 13

Gathering the Cocoons ................................ 14

The Moth ............................................ 15

Choking the Chrysalis ..................................... 16

Shipping the Cocoons .................................... 16

Ants and other Insects ..................................17

Diseases of the Silk Worm.............................17

Varieties or Races ......................................20

Food Plants .........................................21

The Cocoonery .............................................22

Facts that Must be Remembered .........................24

Silk Culture as a Profitable Employment................26

How to Begin Silk Culture................................26

Silk Grower's Requisites................................28 
"AMERICA'S NEW INDUSTRY"

\section{SILK GROWING.}

A COMPLETE

\section{MANUAL OF INSTRUCTIONS}

FOR

\section{SILK GROWERS,}

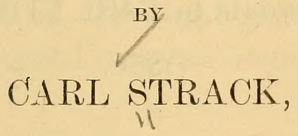

PRESIDENT OF THE ENTERPRISE SILK CO.

PRICE, 25 CENTS,

500 COPIES $\$ 50$.

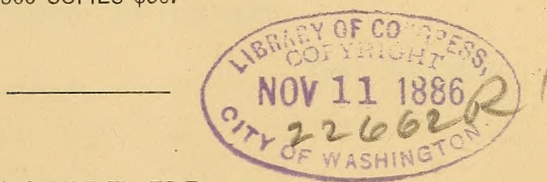

LA SALLE, ILL.

THE ENTERPRISE SILK CO., Publishers. 


\section{SF545 . $\$ 89$}

Copyright by CARL STRACK.

1886. 


\section{PREFACE.}

Though yet in this country in its infancy, Silk growing is surely destined to become, what it is already so justly termed, "America's new Industry" - and while the author does not parade this work as one entirely original, yet he does issue the same with the firm conviction that many of the ideas and instructions advanced, are the result of his own practical experience and observance, and are therefore of much more value in the end, than those given by authors, who (as one very recently admitted to me) "never raised or even owned a worm in their life."

With the hope that this work, containing the combined results of practical experience, and thorough research among books of acknowledged authority, may assist both the amateur and the professional. Silk grower in their endeavor to further increase "America's new Industry", the same is submitted to its readers as a practical and reliable treatise and manual of Silk Culture in all its stages from the "seed" to the reel.

The Author.

La Salle, Sept. 1886. 



\section{THE SILK WORM.}

The Silk Worm exists in four _stages-egg, larva, chrysalis and imago, and we will aim to give as briefly as possibiy the characterictics and details of each of the different stages of its life, beginning with

\section{THE EGG.}

Silk growers generally call the egg of the silk worm, which is nearly round, slightly flattened and of the size of a small pinhead, the "seed."-When first deposited by the moth, it is of a yellow color, and this color it retains if it does not become impregnated. If impregnated it changes color to a gray, slate, violet, or dark green hue, varying somewhat according to breed or variety of the worm:

Each female moth produces from three to four hundred of these eggs, and in the market they are sold by the ounce, which contains from 35,000 to 50,000 of them.

\section{WINTERING THE EGGS.}

These Eggs are now to be preserved until the spring following, and as this is the initiation step in successful Silk Culture we will not only give our own practical experience in this regard, but also append the views of others, who are entitled to credit as successful and authorative culturists. 
After the change in color has taken place the egg should still be left on the tray or shelf, upon which it was deposited, and the atmosphere should rather be moist than too dry, while the temperature during the summer and autumn should not be allowed to vary too much from about $65^{\circ}$ Fahrenheit; when in winter the outside temperature is expected very much lower, they shonld be placed in a cellar and kept at about $20^{\circ}$ below the freezing point, always however bearing in mind that frequently fresh air must be admitted, and mold guarded against. Rats and mice are very fond of the eggs, and must therefore be pruvented from getting at them. They are most safely stored in a dry cellar, where the temperature sinks below the freezing point, and they should be occasionally looked at to make sure that they are not affected by mold. If, at any time, mold be perceived upon them it should be at once rubbed or brushed off, and the atmosphere made drier. If the tin boxes be perforated on two sides and the perforations covered with fine wire gauze, the chances of injury will be reduced to a minimum.

The eggs may also, whether on cards or loose, be tied up in small bags and hung to the ceiling of the cold room. The string of the bag should be passed through a bottle neck, or a piece of tin to prevent injury from rats and mice. The temperature should never be allowed to rise above $40^{\circ} \mathrm{F}$., but may be allowed to sink below freezing point without injury. Indeed, eggs sent from one country to another are usually packed in ice. They should be kept at a low temperature until the mulberry leaves are well started in the spring, and great care must be taken as the weather grows warmer to prevent hatching before their food is ready for them, since both the mulberry and Osage orange are rather late in leafing out. One great object should be, in fact, to have them all kept back, as the tendency in our climate is to premature hatching.-(Riley.) 
The importance of having the eggs free from disease and of good races, has already been shown. They should be kept in tin boxes, to prevent the ravages of rats and mice, and be hung by string or wire from a joist in a cool, dry cellar, where the temperature rarely sinks below the freezing point. They should be occasionally examined to see if they are affected by mould. If this should be discovered on them, it must be carefully rubbed or brushed off of them at once, and they should be put in a drier place. The tin boxes may be perforated on two sides and the holes covered with fine wire netting. The temperature should never be allowed to rise above forty degrees, but may fall to freezing point without injury to the eggs. They should be kept at this low temperature till hatching time, which will be when the mulberry leaves are about the right size for feeding (about the size of $\frac{1}{2}$ dollar), and great care must be taken as the warm weather increases in the spring, to prevent their hatching before the leaves are ready for them. When the warm weather commences, if too early, for their food, enclose the tin box in a wooden one, and place it on ice. As the tendency in our climate is to premature hatching, the great object is to keep them all back, as described above, till their food is plenty.-(Rossiter.) 


\section{HATCHING THE EGGS.}

After the eggs have been carefully kept as advised, and the time has arrived that there will be food for them, the Culturist's holidays are over, and he or she must prepare themselves for a term of patient and faithful work, for without these, success cannot be attained. The trays and shelves (of which we will speak further on) should now be thoroughly dried and disinfected with a weak solution of carbolic acid, (1 part of acid to 30 parts of water) placed in the eocoonery, which should have a temperature of about $70^{\circ}$ Fahrenheit; the eggs are carefully spread out, and the temperature of the room increased about $2^{\circ}$ each day-in about 5 days the eggs will assume a lighter color, and gradually the outline of the coming silk worm may be seen through the shell. The floor should now be sprinkled and kept moist, to assist the worm in breaking the shell more readily.

The early morning hours of the 6th day will usually hatch out about one-half of the entire number of the eggs, and the remainder will follow on the succeeding daythose not hatching out by that time should be discarded, as they are usually of feeble constitution, and will not prove profitable even should they mature. When the proper time arrives, the eggs should be brought out gradually from the cold cellar at forty degrees, to a room at fifty degrees, for one hour; then to a room at sixty degrees for half an hour, and then to hatching room at seventy-five degrees. Keep the temperature as uniform as possible, and if it is increased about two degrees each day it will hasten the hatching of the eggs. As the time of hatching approaches the egers grow lighter in color, and if the floor is sprinkled, to moisten the atmosphere, it will enable the worms to eat through the shell more easily. A small amount of moisture appears to freshen and invigorate them. The worms hatch out from four to eight o'clock in the morning.-(Rossiter.) 


\section{THE WORM.}

The Silk Worm (Bombyx: Mori), immediately after being hatched oit, is hardly 2 millimeters in length, but grows rapidly, and at the end of 4 to 6 weeks is over 8 centimeters long. Its color is at first a dark brown, aimost black, but becomes lighter after each molt, so that at the end of its worm existence it is almost a pure white and transparent.

During its life it passes through 4 molts, each one of which is preceded by a voracious appetite, and after each molt the worm increases perceptibly in size, and changes in color and appearance.

The periods between these different molts are called "ages," there being five of these ages, including the first from the hatching and the last from the fourth molt to the spinning period. The time between each of these molts is usually divided as follows: The first period occupies from five to six days, the second but four or five, the third about five, the fourth from five to six, and the fifth from eight to ten.

The preparation for each molt requires from two to three clays of fasting and rest, during which time the worm attaches itself firmly by the abdominal prolegs (the 8 non-articulated legs under the 6th, 7th, 8th, and 9th segments of the body, called prolegs in contradistinction to the 6 articulated true legs under the 1st, $2 d$, and $3 d$ segments), and holds up the forepart of the body, and sometimes the tail. During the time of preparing for the molt the worm must not be disturbed, or removed. In front of the first joint a dark, triangular spot is at this time noticeable, indicating the growth of the new head; and when the term of "sickness" is over, the worm casts its old integument, rests a short time to recover strength, and than freshened, supple, and hungry, goes to work feeding roraciously to compensate for lost time. This so- 
called "sickness" which preceder the molt was, in its turn, precederl by a most voracious appetite, which served to streteh the skin. In the operation of molting the new head is first disengaged from the old skin, which is then gratually worked back from segment to segment until intirely cast off'. If the worm is feelle, or has met with any misfortune, the shriveled skin may remain on the end of the borly, being hold by the anal horn; in which (ane the individual usually perishes in the course of time.

\section{FEEDING AND REARING THE WORM, 1st Age.}

FROM THE HATCHING TO THE FIRST MOLT.

The young worm should be fed only on small and tender leaves, and some culturists even prefer to chop the food for the very young worm, but, especially for larger colonies, this procerlure would take too much time, and I furthermore do not believe it at all necessary, as in the spring the leaves are small and tender, and nature has frovided the worms with sufficiently strong jaws to cut them.

The food should be renewed whenever the leaves have become in the least dry, which takes place rery soon in the dry atmosphere of the cocoonery, and especially when the leaves are young and tender.

The worms eat most freely in the early morning, hetween 5 and $(; \mathrm{A}$. M., and late at night, between 10 and 11 P. MI.

The Culturist cannot give the worm, during this first and most relicate age, too much care and watchfulness, and should feed them whenever they seem to require it. The leares for the carly morning meal should be pirkerl the evening hefore, as thowe picked and fert with the dew upon them are very apt to induce disease. An invariable rule should be, never to feed wet or damp leaves to your worms. In ease 
they are picked during a rain, they should be thoroughly dried before being fed; and on the approach of a storm it is wise to lay in a stock, which should be occasionally stirred, to keep them from heating.

As the fifth or sixth day approaches, signs of the first molt begin to be noticed. The worm begins to lose appetite and grows more shiny, and soon the dark spot already described, appears above the head. Some will shed their skin more easily and quickly, than others, but no food should be given these forward ones until all have completed the molt. This serves to keep the batch together, and the first ones will wait one or even two days without injury from want of food. The importance of keeping each batch together, and of causing the worms to molt simultaneously, cannot be ton much insisted upon as a means of saving time.

As soon as the great majority have molted they should be copiously fed, and, as they grow very rapidly after each molt, and as they must always be allowed plenty of room, it will probably become necessary to divide the batch, and this is readily done at any meal by removing the net when about half of the worms have risen and replacing it by an additional one. The space allotted to each batch should, of course, be increased proportionately with the growth of the worms. The young worms may be removed from place to place by merns of a small camel's-hair brush, but should be handled as little as possible. The same precautions should be observed in the three succeeding molts as in this first one. 


\section{Second, Third and Fourth Ages.}

From now on, up to the time of spinning, the worms daily require larger quantities of food, and the daily removal of all excrement and litter.

The second and third casting of the skin take place with but little more difficulty than the first, but the fourth is more laborious, and the worms not only take more time in undergoing it, but more often perish in the act. At this molt it is perhaps better to give the more forward individuals a light feed as soon as they have completed the change, inasmuch as it is the last molt and but little is to be gained by the retardation, whereas it is important to feed them all they will eat, since much of the nutriment given during the last age goes for the elaboration of the silk. At each successive molt the color of worm has been gradually whitening, until it is now of a decided cream color. Some breeds, however, remain rark, and occasionaly there is an individual with zebralike markings. During these last few days the worms require the greatest care and attention. All excrement and litter must be removed often, and the sickly and diseased ones watched for and removed from the rest. The quantity of leaves which they devour in this fifth age is something enormous, and the feeding will keep) the attendant busily employed.

It has been usually estimated that the worm in its growth consumes its own weight of leares erery day it feerls; but this is only an approximation. Yet it is certain that fluring the last few days beforc ("ommencing to spin, it consumes more than during the whole of its previous worm existence.

Summed mp, the requisites to suceessful silk wom latising are, 1st. Iniformity of age in the individuals of the same tray, so as do insure their nolting simultaneously.

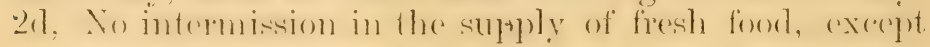


during the molting periods. B̈d, Plenty of room, so that the worms may not too closely crowd each other. 4th, Fresh air and as uniform temperature as possible. 5th, Cleanliness. The last three are particularly necessary during the fourth and fifth ages. While small, the frass, dung, and detritus dry rapidly, and may (though they should not) be left for several days in a tray with impunity; but he who allows his trays to go uncleaned for more than a day during the ages mentioned will suffer in the disease and mortality of his worms just as they are reaching the spinning point.

A crop from hatching to spinning will occupy from 30 to 35 days if all details have been properly attended to by the culturist.

\section{PREPARATIONS FOR SPINNING.}

With eight or ten days of busy feeding, after the last molt, the worms, as we have learned before, will begin to lose appetite, shrink in size, become restless, and throw out silk, and the arches for the spinning of the cocoons nust now be prepared. These can be made of twigs of different trees, two or three feet long, set up upon the shelves over the worms, and made to interlock in the form of an arch above them. Interlace these twigs with broom corn, hemlock, or other well-dried brush. The feet of each arch should be only about a foot apart. The temperature of the room should now be kept obove $80^{\circ}$, as the silk does not flow so freely in a cool atmosphere. The worms will immediately mount into the branches and commence to spin their cocoons. They will not all, how(rer, mount at the same time, and those which are more tardy should be fed often, but in small quantities at a time, in order to economize the leaves, as almost every moment some few will quit and mount. There will always be a few which altogether fail to mount, and prefer to spin in their trays. It is best, therefore, after the 
bulk have mounted, to remove the trays and lay brush carefully orer them. The fact that the worms already momnteil make a final discharge of soft and semifluid excrenent hefore beginning to spin makes this separation necessary, as otherwise the cocoons of the lower ones would be badly soiled.

As the worms begin to spin they should be carefully watched, to guard against two or three of them making what is called a double or treble cocoon, which would be unfit for reeling purposes Whenever one worm is about to spin up too near another, it should be carefully removed to another part of the arch. In two or three days the spinning will have been completed, and in six or seven the chrysalis will be formed.

\section{GATHERING THE COCOONS.}

A week from the time the worms begin to spin the cocoons should be harvested, by taking the arches carefully apart, and carefully removing the thin and spotted cocoons, so that they may not soil the clean ones.

The "Cocoon" is tough and compact, and is composed of a continuous thread of silk, which is strong and firm, and is spun by the worm in figure of $\mathrm{S}$ shaped loops. Its shape is generally oval or egg-shaped, and varies in color, the commonest of which are the yellow, straw or cream color, white and green. These are supposed to denote the nationality of the worm spinning them. The larger sized, rounder formed, cocoons, denote the females, while the males are more slender shaperl, depressed in the centre and pointed at both ends. This is generally used as a rule among growers. The onter lining of the cocoon is a loose silk spun by the worm when prepraing for its final work. It is called flock, or floss, and sells with the pierced cocoons and other waste silk. This cannot be reeled, but is carded and spun by the manufacturers. 


\section{THE MOTH.}

If the object is to raise eggs, the largest, best shaped, and firmest cocoons should be selected, chosing an equal number of each sex, which can be however only approximately done by weighing a quantity of them, and then determining the females by their weight, being over the average. The selected cocoons are now laid aside in a dark but ventilated room for twelve or fifteen days, when the moth will emerge from them.

In producing moths from cocoons, the temperature must not be too high, not above $73^{\circ}$, or the transition would be too rapid and result in an enfeebled moth. In the transformation from worm to moth, there is no disposition to wander; the fly will spend its short span of life within its limits.

The moth finds some difficulty in escaping. For this purpose it is provided, in two glands near the absolute rnouth, with a strongly alkaline liquid secretion with which it moistens the end of the cocoon and dissolves the hard gummy lining. Then, by a forward and backward motion, the prisoner, with crimped and damp wings, gradually forces its way out, and when once out, the wings soon expand and dry. The silken threads are simply pushed aside, but enough of them get broken in the process to render the cocoons from which the moths escape comparatively useless for reeling.

The moth is of cream color, with more or less distinct brownish markings across the wings. The males have broader antenne or feelers than the females, and may, by this feature, at once be distinguished. Neither sex flies, but the male is more active than the female. 'They couple soon after issuing, and in a short time the female begins depositing her eggs, whether they have been impregnated or not. 


\section{CHOKING THE CHRYSALIS.}

Those cocoons not used for raising eggs, should now be placed on shelves and in a tight box, and an opening made to fit a pipe attached to a steam boiler, and the steam then turned in. Twenty minutes will suffice to choke the chrysalis, and the cocoons are then dried in the sun.

After choking in this manner, the cocoons should be strewn upon long wooden shelves in the shade, witl: plenty of air, and, for the first few days, frequently stirred. After remaining on these shelves for about two months, with occasional stirrings, the chrysalids become (puite dry and the cocoons will preserve indefinitely. They are, however, still subject to the attacks of rats and mice, and the little beetles known as "museum pests," belonging to the genera Dermestes and Anthromus, are attracted by the dead chrysalis within and will penetrate the cocoon, injuring it for reeling purposes.

\section{SHIPPING THE COCOONS.}

Now, that they are thoroughly stifled, take ofl all floss silk, and sort the cocoons, placing all of the firmest and of one color together-the satins which are smooth and glossy like satin, together; the thinest, the doubles and most inferior apart, as these points affect their marketable value very greatly. They should be carefully packed (not crammed) in hags or barrels for transportation. Floss silk and pierced cocoons being of inferior value can be lacked in coarse hags, and as express charges tax sererely hary transfers, it would be best to pack in bags altogether.- (Long.) 


\section{ANTS AND OTHER INSECTS.}

Great care should be taken to guard against the incursions of ants and other predaceous insects, which would make sad havoc among the worms were they allowed an entrance, and all through the existence of the insect, from the egg to the moth, rats and mice are on the watch for a chance to get at them, and are to be feared almost as much as any other enemy the silk worm has.

\section{DISEASES OF THE SILK WORIM.}

It would be folly for the author of this work to attempt to give either a list of the diseases of the silk worm, or their remedy, for as he has never yet liad any discases among the worms raised by him, his experience in this direction is not of practical observation, and therefore we take this chapter from the able pen of Prof. C. T. Riley, whose extended knowledge, thorough research and official position have given, him opportunity to thoroughly investigate the ailments of the silk worm, both in this country and Europe:

As regards the enemies of the silk worm but little neerl be said. It has been generally supposed that no true parasite will attack it, but in China and Japan great numbers of the worms are killed by a disease known as uji, which is undoubtedly produced by the larva of some insect parasite. Several diseases of a fungoid or epizootic nature, and several maladies, which have not been sufficiently characterized to enable us to determine their nature are common to this worm. One of these diseases, called muscardine, has been more or less destructive in Europe for many years. It is of precisely the same nature as the fungus (Empusa muscae), which so frequently kills the common house fly, and which sherls a halo of spores, readily seen upon the window pane, around its victim. $* * * * * * *$ It appears that no 
remerlies are known, but that care in jrocuring good egos, carc in rearing the worms, gooul leares, pure, even temperatured atmosphere, and deanliness are checks to the disease. The trays and other olgects with which the diseaserl worms may have been in contact should be purified by fumigations of sulphurous acid, produced by mixing hisulphite of soda with any strong acid, or, letter still. hy suljecting them to a carbolic acid spray from an atomizer. In this way all fungus spores will be destroverl, In fact it will be well to wash off the trars or shelve once in a while with diluted carbolic acid as a sure prevention. It is one of the best disinfectants known to science

Another disease, known as pebrine, has proved extremely fatal in southem Europe, and for twenty years has almost paralyzed silk culture in France. It is a direare which, in its nature and action, except in being hereditary, bears a striking analogy to cholera among men. "The worms affected by pebrine grow unequally, become languid, lose appetite, and often manifest discolored spots upon the skin. They die at all ages, but, as in musectrine, the mortality is greatest in the last age. The real nature of this malady was for a long time unknown. In 1St:) M. (inerin-Meneville first noticed floating corfuscles in the bodies of the diseased worms. These corpuscles were supposed by him to be endowed with independent life, but their motion was afterwards shown by Filippi to depend on what is known as the Brownian notion, and they are known either by the name of penhistoplyton. first given them by Lebret, or by that of pestropermia. They fill the silk canals, invade the intestines, and spread throughout the tissues of the animal in all its different stages: and though it was for a long time a mooted question as to whether they were the true aumse or the mere result of the disease, the praisowrthy researches of Pasteur have demonstrated that pebrine is entirely deprendent upon the presence and 
multiplication of these corpuscles. He has analyzed the disease so clearly that not only do we see its nature, but are able to point out the remedy. The disease is both contagious and infections, because the corpuscles which have been passed with the excrement or with other sccretions of diseased worms have been taken into the alimentary canal of healthy ones in devouring the soiled leaves, and because it may be inoculated by wounds inflicted by the claws. It is hereditary on the mother's side, because the moth may have the germ of the disease and yet oviposit. Indeed, the eggs may be affected and yet look fair and good, the microscopic psorospermix not being visible, so that the only true test of disease or health is an examination of the parent moth; and by killing off all infected moths the disease can be controlled.

"Both the diseases mentioned are, therefore, in the strict sense of the word the silk worm plagues; the one of a fungus and the other of an epizootic nature. Each become epidemic when the conditions are favorable for the undue multiplication of the minute organisms which produce them, or when the checks to the increase of such organisms are removed by carelessness or ignorance." Cleanliness and purification are absolutely necessary in treating both these diseases, and in pebrine care must be taken that the eggs are sound by a microscopic examination of the moths. This may be done after the eggs are laid, and if the corpuscles be found in the mother her eggs should be discarded.

Silk worms are subject to other diseases, but none of them have ever acquired the importance of those described. What is called gattine by older authors is but a mild phase of pebrine. The worms are apt to be purged by unwholesome leares; too great heat makes them sickly; or they may become yellow, limp, and die of a 
malady called grasseric or jaundice, which is almost sure to appear in large broods, and which is very common in those reared in this country. W'hen the worms die from being unable to molt they are called lusettes, and such cases are most abundant at the fourth molt. All these different ailments, and others not mentioned, hare receired names, some local, others more general; but none of them warrant further notice here, as they are not likely to become rery troublesome if proper attention and care be given to the worms.

\section{VARIETIES OR RACES.}

The different varieties of silk worms have been producerl by domestication. The different climates into which it has been carried haring effected changes in the habits of the worm, the shape and color of the cocoon, or the quality of the silk. There are different varieties of the silk worm:- the "Annual," which produces only one crop of silk in a year; the "Biroltin," or "2-crop worm," which, like the "Annual," hatches in April or May; and which unlike the Anmual, again hatches for a second crop in eight to twelve days after the eggs are laid by the first brood. The eggs of this second brood are always laid away for the next spring crop; for if hatched they would not live, there being no food for them so late in the season, and the weather being unfit to rear them. "Trivoltins" produce three ammal broods. There are also "(zuadrivoltins;" and, in Bengal, a species known as "Dacey" is sin to produce eight broods in the course of a year. Some varieties molt only three times insteal of four-ejecially in warm countries-as also do the "Trivoltins." The "Annuals" only are recommended for this country. Varieties are also known by the color of their oncons, "greens, whites and yellows," and also by the comntry in which they best flourish. The most noted varictics are "Italian," producing fine, mall, yellow cocoons: "French," producing large, yellow and straw- 
colored cocoons; "Turkish," producing large, white cocoons; the "Japanese," white and green, and the "Chinese," white cocoons. Some of these are "Annuals," but the different colored cocoons are generally called by the above name. The silk of the "white" cocoons is the most valuable in commerce, but the "straw-colored" is most sought after. The races producing the yellow and straw-colored cocoons are considered the most vigorous. -(Rossiter.)

\section{FOOD PLANTS.}

The usual food for the silk worm is the mulberry, the "white" being the best and the "purple" the next. The "paper" mulberry is not good for them and should be avoided.

The following directions are from a practical raiser for growing standard trees: The cuttings should remain in the nursery two years without pruning. The third year cut close to the ground and transplant. Allow the finest shoot to grow, and if the land is good it will grow eight to ten feet in height in one season. The fourth year cut it back to about six feet. Then allow the three or four terminal buds only to grow, removing the others as often as they appear, by passing the hand along the stem. The "Morette," a variety of white mulberry, is profitably grown in hedges. It is very desirable on account of the large size of its leaves. The cultivation of the Osage Orange is well understood in this country. As it is generally used as a hedge in those parts of the country which are specially adapted to silk culture, the leaves may be readily obtained, and as the hedges need trimming, the cutting of the new growth each year as the leaves are wanted for food, is a saving rather than an expense. Those using this plant for food for silk worms must remember, that as the shonts from a hedge-row become more vigorous, milky and succulent by the time of the 
last age of the worms, the terminal leaves should not be used, but thrown aside, as they are likely to induce disease. If ware be taken in this respect, there will be no alplarent difference hetween the silk (rop) and that of the mulberry. Should the worms from any cause hatch hefore cither Mulberry or Osage Orange leaves can be whaned, they may be successully fied for a few days on dried "lettuce or clindelion leaves," but it is worse than a urchess waste of time to attempt fecting them cutirely on these, or the leares of any other plants than the two here recommended.

\section{THE COCOONERY.}

The room in which the rearing is done is usually called the cocoonery. It should have a north-eastern exposure. The air should be kept pure all the time, and arrangement- made to secure a good circulation. It whould be well lighten. If buildings are erected expressly for the furpose, they must combine all these. If only a small number of worms are to be raised, a few trays placed on tables will be all that will be required. If, howerer, large numbers are reared, frames or racks and trays must be providerl, the wood, in all cases, to be well seasoned. Make upright frames around the room, to hold the number of trays to lie used to accommodate the worms raised. The worms must not be huddled too closely together, as they need plenty of room for feeding and rentilation. If too many are kept together in the trays, they cannot feed properly-it is more difficult to change them-and it also tends to create disease among them. The trays are formed of thin frames like laths, set edgeways-say 16 inches by 24 inches. (This will be a good size for handling easy.) Drive tacks half way in, on the under side of the frames, all around, about half an inch apart. Then take good strong twine, not too thick, run it from tack to tack lengthways of the frame, stretching it tightly-then crossways, interlapping it so 
as to make a firm support for the musquito netting, leaves and worms. After stretching the twine on the frame, drive the tacks in to the heads, and the tray is complete. A tray of this size will hold and feed 1000 worms at first and second age, after which time they must be separated as they grow larger, placing them on otller trays. Have mosquito netting (white) cut so as to fit the trays-providing enough to have changes every day, which must be attended to, as cleanliness is actually necessary for the health of the worms. Change them early in the morning, and hang the netting used over night, up to air. When the worm is first hatched, tarletan is used in place of netting (the meshes of which are too large). On this sprinkle some fresh, tender leaves. The little worms will leave the eggs and immediately commence eating, and from this time constant attention must be paid to renewing the leaves as often as may be required; and as the worms eat fast, and the leaves dry rapidly, they need replenishing often. 


\section{FACTS THAT IMUST BE REMEIMBERED.}

A miform temperature is rery inmortant and necessary in silk growing. The temperature should nerel fall below $70^{\circ}$, nor raise much above $30^{\circ}$. 'If extreme hot wather should set in, the Hoor should be sprinkled or wet choths humg up in the rearing room to keepe the temperature down.

Tentilation is an important factor in suceessful silk growing, and must be strictly attenderl to, but a draft directly upon the worms must never be allowed.

C'leanliness cannot be too much insisted upon, and the clearing of the litter every alternate day during the first and second ages, and crery day during the $3 d$, the and 5th ages dare not be omitted.

Give all your trays a thorough airing whenerer they are empty, and spraying them with a solution of carbolic acid, of the strength already mentioned in another part of this work, will do much toward preventing disease among your little army of spinners.

Never allow the worms to become crowded, give them plenty of room, especially as they near the the and 5th ages.

Terer feed wet or damp food, as this will purge the worms.

A large quantity of food at one time, is only a waste, and will not save you from feeding them often.-Bear this in mind.

The direct rays of the sum falling upon them will kill the worms.-Sudden changes from warm to cold, or viceversa are hurtful and dangerous.

Too great heat makes them sickly. 


\section{- 25}

See that the leaves fed are clean, and that no other leaves than the mulberry, or Osage Orange be fed. Tobacco smoke is poison in a cocoonery.

Birds and insects of all kinds are enemies of the silk worm.

Be sure you procure good eggs, or your entire labor of a season may result in a failure. The Eggs sold by Thw Enterpilise Silk Co. of La Salle, Illinois, are all microscopically examinerl, and therefore positively free from discase, and furnisher at as low prices as reliable seed can be procured. 


\section{SILK CULTURE:}

\section{AS A PROFITABLE EMPLOYMENT.}

Many thousand of woman and children are mabie to labor in shop, field, or tactory, and have no other means of converting their labor into capital. To such, and thousands of others, silk culture is an easy and moner making employment ut home, as it requires but a smail amount of labor and outlay, and is peculiarly adapted to the skill and eare naturally possessed by women.

\section{HOW TO BEGIN SILK CULTURE.}

A book of instruction, about $\frac{1}{3}$ or $\frac{1}{2} \mathrm{or}$ of good eggs, an Oarge orange hedge, and a room, are all that are necessarily needed for a start.

To special builelings are rectuired, and silk culture does not interfere with domestic duties.

Use nothing but the best Eggs.

For a begiming send to The Exterprase siLk ('o., La salle, Inlinois, for the following articles, and you are ready to make a good start:

1 Book of Instructions....................... \$. 25

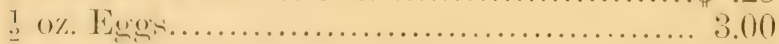

Tray and Frames (as models)............... 1.50

Perforated Paper for all ages ................ $\quad .50$

$\$ 5.25$

Acheses all communications, and enclose return postage to

CART, S'TRACK, Pres.

THE ENTERPRISE SILK CO., La SALLe, Ilti. J. (. I) AWKINS, Sec, \& Treas. 



\section{8 \\ SILK GROWER'S REQUISITES.}

The Enterprise Silk Co. of La Salle, Illinois, is composed of practical and successful silk growers, and their aim is to make this new industry become more general, and furnish both pleasant and profitable employment to the many thousands whose constitutions and positions will not permit them to labor in the field or factory. This Company therefore furnishes none but the very best of everything needed by the Culturist.

Our Silk Worm Eggs are all microscopically examined, and can be relied upon.

We append herewith our list of prices, which are lower than PRIME goods can be offered by any other house.

\section{PRICES OF SILK WORM EGGS.}

Japanese annuals, white and green ....................... per oz. $\$ 6.00$

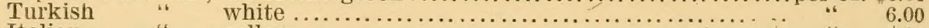

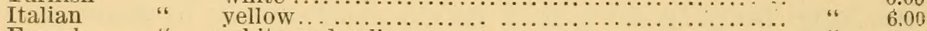

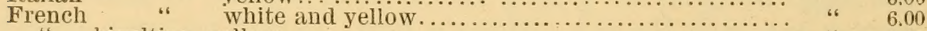

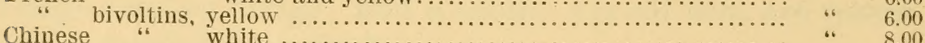

Full instructions for hatching sent with every order. Eggs should be ordered as early as possible in the winter months.

PRICES OF MULBERRY SEED.

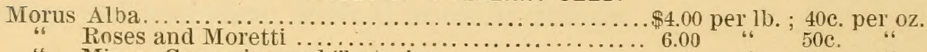
Migra, Caucasian and Tartarica...................... ". $8.00 \quad$. $60 \mathrm{c}$. "

PRICES OF REQUISITES.

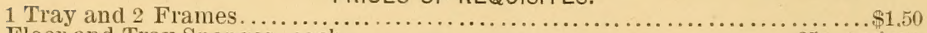

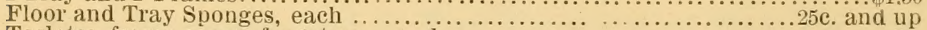

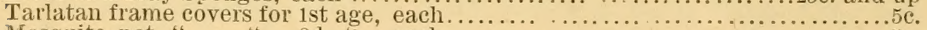

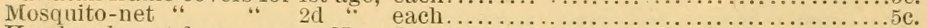

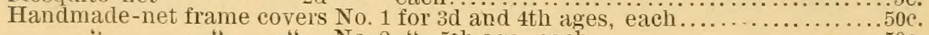

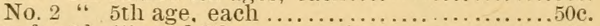

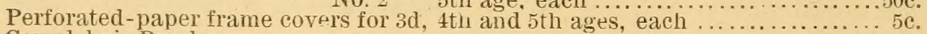

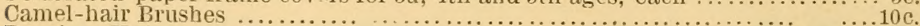
Pruning Knives, each ... ... ................................... to $\$ 1.50$

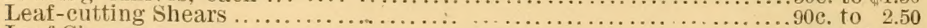

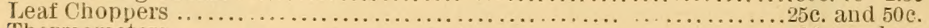

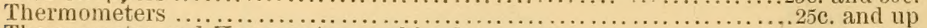

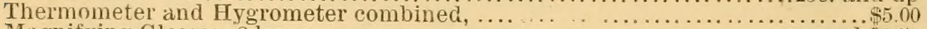

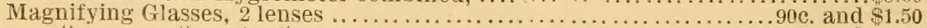

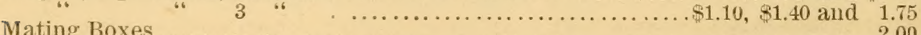

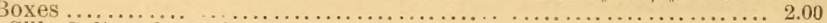

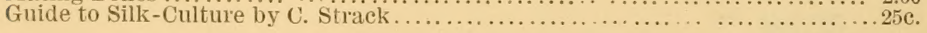

\section{HOW TO SEND ORDERS.}

Orders must give reference or be accompanied by cash, (by express, or postal order, or check, or registered letter.) Cash orders have preference, and are guaranteed to be filled immediately. Goods will be shipped C. O. D. if one quarter of the price accompanies order. Address all orders to

CARL STRACK, Pres, 


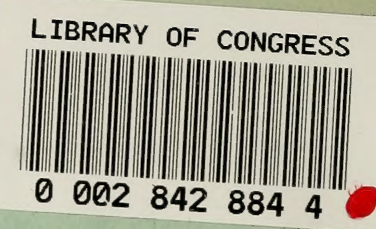

